\title{
Larval Transport and Recruitment of Pacific Hake Merluccius productus
}

\author{
Kevin M. Bailey \\ College of Fisheries, University of Washington, Seattle, Washington 98195, USA
}

\begin{abstract}
The advection of Merluccius productus larvae offshore appears to be a significant factor in establishing recruitment levels. Pacific hake spawn mostly in January and February over the continental slope in the area of study. The offshore distribution of larvae is positively correlated to offshore Ekman transport, while year class strength and offshore Ekman transport at the time of spawning are negatively correlated. Since the juvenile nursery is inshore over the continental shelf, larvae advected seaward of the continental shelf probably have poor survival as juveniles. Larval survival also appears to be poor in cold years of strong offshore transport. A multiple regression model accounts for $72 \%$ of the variance in an index of year class strength.
\end{abstract}

\section{INTRODUCTION}

Environmental conditions during the planktonic stages of marine fishes have important consequences for stock recruitment. One of the factors affecting the year class strengths of marine fishes is the advection of eggs and larvae offshore away from favorable nursery areas. This appears to be especially important to fishes whose nurseries are inshore since correlations of year class strength with wind direction and speed at the time of spawning have been found for several such species (Nelson et al., 1977; Riley et al., 1979). These correlations assume that eggs and larvae are transported offshore by wind driven transport of surface waters, but this assumption has not been verified.

From the results of developmental studies on marine fishes, temperature would also seem to be an important ecological factor in recruitment. At higher temperatures development is faster through egg and yolk sac stages, which should mean less mortality from invertebrate predation. Metabolic rates are also greater from increased activity, so that food searching potential is greater, as is food demand. Temperature is often correlated to recruitment of marine fishes, although the mechanism has been unclear.

Recruitment to the Merluccius productus population is extremely variable, evidenced by strong year classes appearing in the stock and dominating catches for 3-4 years (Fig. 1). The availability of data on planktonic, juvenile and adult stages, and the unique biological characteristics of the life history of Pacific hake make it an appropriate species for this study of recruitment. Historical records on hake larvae from the CalCOFI ichthyoplankton surveys are available dating back to 1950 , as are data on adults and juveniles from Northwest and Alaska Fisheries Center trawl surveys dating
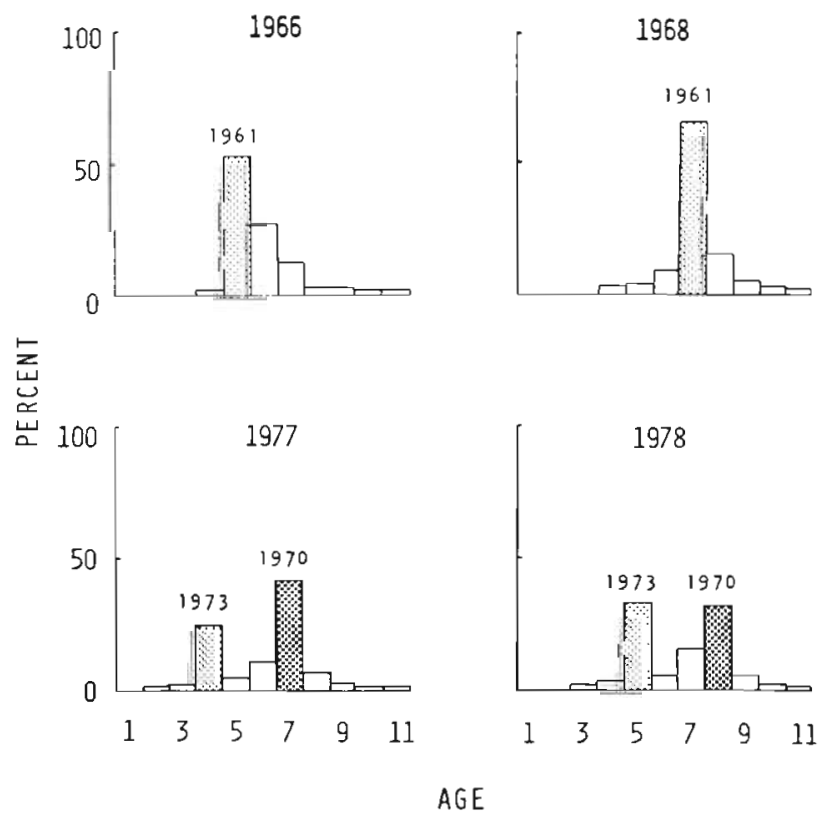

Fig. 1. Merluccius productus. Age compositions of hake caught off Oregon and Washington from research surveys (1966 and 1968) and from U. S. Observer fishery data (1977 and 1978) 
back to 1963. In this study these data are used to examine the relationship between environmental events and the distribution and survival of larvae, and to examine the relationship between these events and recruitment.

\section{METHODS}

Data on Merluccius productus Iarvae from the CalCOFI surveys used in this study were recorded in standardized numbers under $10 \mathrm{~m}^{2}$ sea surface. The methods of collecting and summarizing the CalCOFI survey data are reported by Smith and Richardson (1978). After 1963, hake larvae were measured and recorded by size class. I sized larvae from the April surveys of 3 prior years, 1955, 1960 and 1961, for this study. Data used to examine the distribution of juvenile hake were available from the 1977 summer bottom trawl survey of the Northwest and Alaska Fisheries Center (NWAFC) and from a series of midwater trawl surveys conducted by the California Depart. ment of Fish and Game and reported in the CalCOFI Data Report Series beginning in 1964

An index of cohort strength was necessary to compare the interannual changes in recruitment success. Historical fishery data on Pacific hake necessary for cohort or CPUE analyses were not available. Historical survey data were also not adequate for CPUE analysis due to small sample sizes and patchiness in fish distribution. I chose to establish a relative index of year class strength ( $\mathrm{YCI}$ ) representing the dominance of a

Table 1. Merluccius productus. Year class index formed from the percent contribution of each cohort from ages $4-6$ years in summer surveys off the Oregon-Washington coast, mosliy in the Columbia region (1960-71) and from U.S. observer data on foreign vessel catches in the Columbia region (1972-75)

\begin{tabular}{rrrrrr|}
\hline & \multicolumn{9}{c}{ Percent at age } & Sum $=$ & Log \\
Year & 4 & 5 & 6 & YCl & (YCl) \\
\hline 1960 & 2 & 23 & 29 & 54 & 1.73 \\
1961 & 20 & 45 & 65 & 130 & 2.11 \\
1962 & 1 & 1 & 12 & 14 & 1.1 .5 \\
1963 & 1 & 2 & 16 & 19 & 1.28 \\
1964 & 2 & 9 & 9 & 20 & 1.30 \\
1965 & 1 & 1 & 6 & 8 & 0.90 \\
1966 & 1 & 7 & 12 & 20 & 1.30 \\
1967 & 5 & 11 & - & 34 & 1.53 \\
1968 & 3 & - & - & 28 & 1.46 \\
1969 & - & - & 15 & 29 & 1.48 \\
1970 & - & 28 & - & 78 & 1.89 \\
1971 & 1 & - & 8 & 18 & 1.25 \\
1972 & - & 5 & 6 & 14 & 1.14 \\
1973 & 23 & 33 & 29 & 86 & 1.93 \\
1974 & 4 & 4 & 8 & 16 & 1.20 \\
1975 & 4 & 9 & - & 30 & 1.47 \\
\hline
\end{tabular}

cohort in the catch composition of annual research trawl surveys and from U.S. observer data on the foreign fishery in summer off the Oregon-Washington coast. This was formed by summing the percentage of the total annual age composition contributed by each cohort over the ages $4-6$ years (Table 1 ). One or more age frequencies for a year class from non-survey years were often missing and the index was estimated from the regression equation of $\mathrm{YCI}$ against age frequency using the available age frequencies. These regression equations were:

$\mathrm{YCI}$ from age 4 frequency: $\mathrm{YCI}=17.8+3.4 \mathrm{X}, \mathrm{R}^{2}=0.72$ $\mathrm{YCl}$ from age 5 frequency: $\mathrm{YCI}=4.6+2.6 \mathrm{X}, \mathrm{R}^{2}=0.96$ $\mathrm{YCI}$ from age 6 frequency: $\mathrm{YCI}=-3.3+2.2 \mathrm{X}, \mathrm{R}^{2}=0.90$.

Where two regression estimates existed, the estimate of the year class index was the average of the two regression estimates.

Individual values of the year class index are deter. mined not only by the abundance of the year class, but also by the abundance of adjacent year classes. Thus, the $\mathrm{YCl}$ is not an absolute measure of abundance, but should be useful for comparing recruitment success between neighboring years as long as the spawning potential of the stock is similar. Tester (cited by Ketchen, 1956) reports that this type of index reflects changes in the relative abundance of year classes, but may differ from absolute values in amplitude and in long term trends.

The validity of the index as a measure of year class strength was checked by comparing the actual annual abundance of hake larvae found in CalCOFI surveys to the predicted abundance of eggs calculated from a population simulation, where the year class index was used as the relative number of 4 years olds entering the spawning population. In the simulation the number of eggs contributed in each year (j) by each year class (i) is calculated as:

$$
E_{i j}=N_{i j} \times f_{i j} \text {, where } N_{i j}=N_{i-l, j-l} \times e^{-(F+M)}
$$

where $(E=$ total eggs; $\mathrm{f}=$ fecundity; $N=$ relative number of fish; $F=$ fishing mortality since 1966; $\mathrm{m}=$ natural mortality. The values approximating $\mathrm{F}$ and $M$ have been estimated as 0.4 and 0.35 (Bailey, 1980). A fecundity schedule was adapted from MacGregor (1966). The total number of eggs produced in each year by the main spawning population is:

$$
\sum_{i=4}^{8} E_{1 j}
$$

The annual larval abundance was calculated as the number of larvae in January surveys. Since variations in the time of spawning and development must occur, the January abundance was adjusted by a factor empirically developed to account for possible late 
spawning. This factor was: $\log (1000 \times$ larvae [2-3 $\mathrm{mm}$ ] per station in April/larvae [2-3 mm] per station in January). January and April surveys occurred in almost all survey years, whereas February and March surveys occurred infrequently. Fig. 2 shows that the relative number of eggs produced each year as predicted by the YCI compares fairly well with the actual observed abundance of larvae.

It was possible to test theoretically the precision of the YCI as a relative measure of recruitment using a stochastic simulation. Randomly generated numbers were used as the hypothetical actual number of 4 year olds (RN). The RN's were generated to vary about 200fold (to simulate fluctuations in recruitment) and to have a normal distribution. The numbers of each age class for 100 years were calculated with the equation

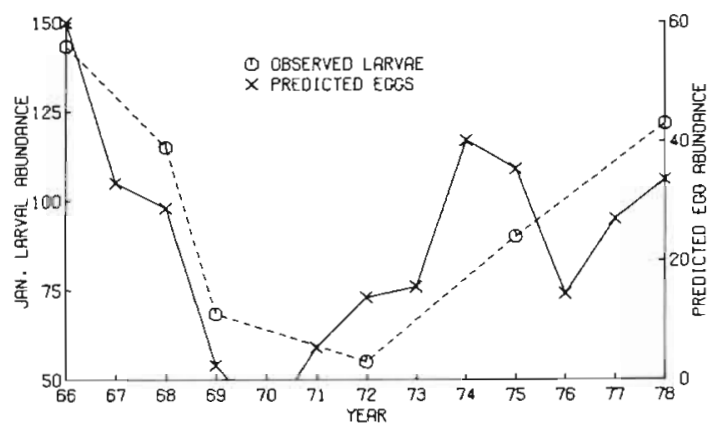

Fig. 2. Merluccius productus. Larval abundance determined from January surveys conducted in 1966, 1968, 1969, 1972 , 1975 and 1978 , compared to the abundance of eggs predicted from the index of year class strength

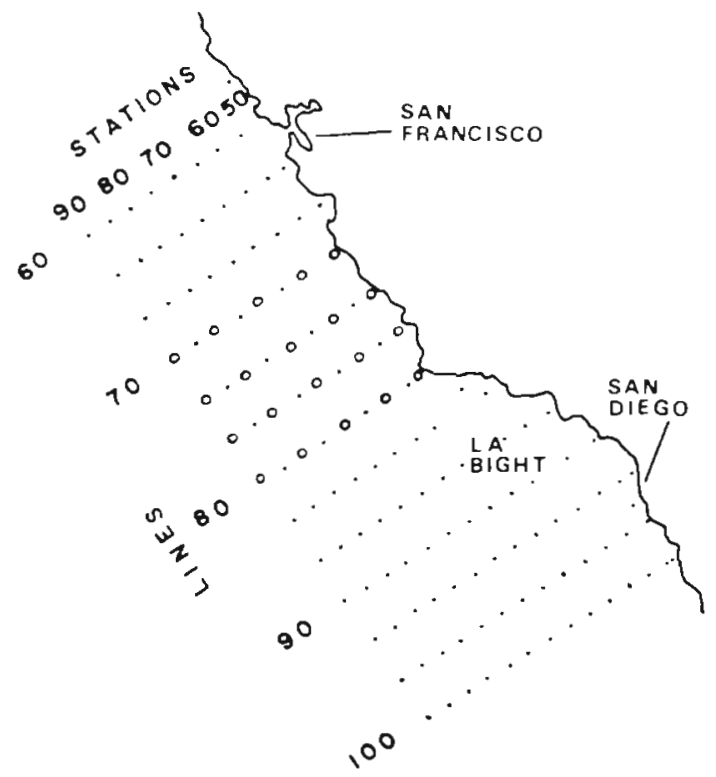

Fig. 3. Merluccius productus. Section of the CalCOFI survey region where larvae are most abundant. Also shown is the grid used in examining the offshore distribution of larvae (larger open circles)

$$
N_{4+1}=N_{4} \times e^{-(F+M) \times 1}
$$

where $N_{4}=R N$ (the number of 4 year olds); F and $M=$ the same values used previously. A $(100 \times 14)$ matrix of year by age class was filled with cohort numbers at age. From this matrix the YCl was calculated as described above.

The relationship between $\mathrm{YCl}$ and RN was approximately linear, but the residual variance increased with $R N$, therefore a log-transformation was appropriate. In the log-transformed variables, $90 \%$ of the variance in $\mathrm{YCI}$ was explained by changes in $\mathrm{RN}$. The regression equation is: $\log (\mathrm{YCI})=0.85 \times \log (\mathrm{RN})+0.54(\mathrm{r}=$ $0.95, \mathrm{P}<0.001)$. Confidence intervals $(95 \%)$ on $\mathrm{YCI}$ from a given $\mathrm{RN}$ are $\log (\mathrm{YCI} \pm 0.27$ ). In practice these confidence intervals are wide and overlapping for comparisons other than high versus low indices.

The offshore distribution of hake larvae was examined between CalCOFI lines 70-80 using a 4 line, 20-station grid that extended 160 nautical miles seaward (Fig. 3). This area was examined because: (1) hake larvae are usually abundant there; (2) the grid region was usually surveyed, although the grid was not always completely covered, especially in the 1950 's; (3) a well-defined continental slope exists in the region. I did not survey the Los Angeles Bight region because offshore banks and islands are numerous in the Bight, and hake appear to spawn in these areas, whereas in the grid region they spawn over the slope (Bailey 1980). The mean distance of larvae offshore was calculated as $\Sigma D \times \log (\mathrm{N}) / \Sigma \log (\mathrm{N})$, where $\mathrm{N}=$ number of larvae station ${ }^{-1} ; D=$ distance of the station offshore. A log-transformation was used to reduce the effects of patchy catches of large numbers of larvae that were probably recently hatched (Elliott, 1977).

Upwelling indices used in this study are from Bakun (1973, 1975), sea level heights at San Francisco were provided by $A$. Bakun, and the average sea surface temperature in the Los Angeles Bight during the spawning months (January-March) was used as an index of temperature (Johnson et al., 1978).

Standard statistical packages were used for simple and multiple regression analyses.

\section{RESULTS}

\section{Offshore Distribution and Transport of Larvae}

Most spawning activity of Merluccius productus takes place from January until April, but is concentrated in January and February (Bailey, 1981). CalCOFI survey data from the main spawning months were analyzed from a section of the CalCOFI area (Lines $70-80$ ) to examine the offshore distribution of larvae. Since spawning in this region occurs over the 
Table 2. Merluccius productus. Correlation coefficients of mean monthly larval distance offshore against the monthly upwelling index

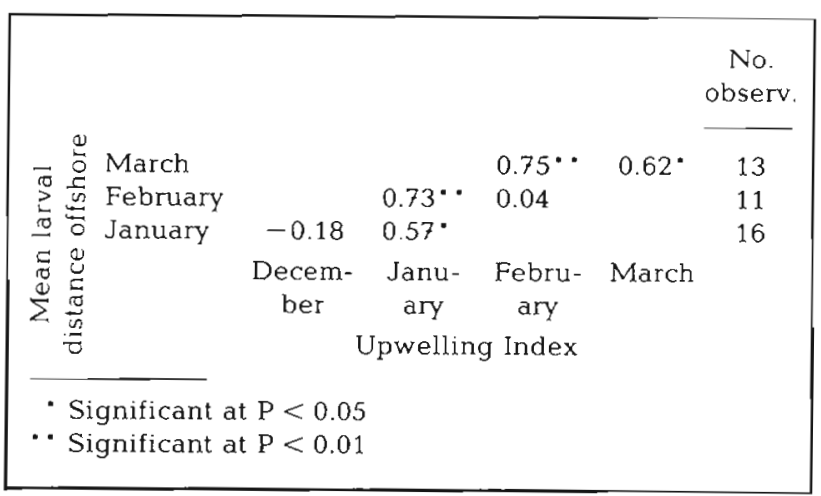

continental slope, larvae found away from the slope must have been transporled by ocean cuirents. In this analysis upwelling indices from Bakun $(1973,1975)$ at $36^{\circ} \mathrm{N}$ latitude were used as indices of offshore transport of surface water, approximated by wind stress. According to Ekman theory, equatorward winds cause offshore transport of the surface layer in proportion to the magnitude of the wind stress. A positive upwelling index indicates offshore transport; a negative index indicates onshore transport.

The mean distance of larvae from the coast within the grid region is quite variable between years and is positively correlated to Ekman transport. The mean distance of larvae offshore in both January and February is most highly correlated to Ekman transport in January (Table 2), indicating that larvae caught in

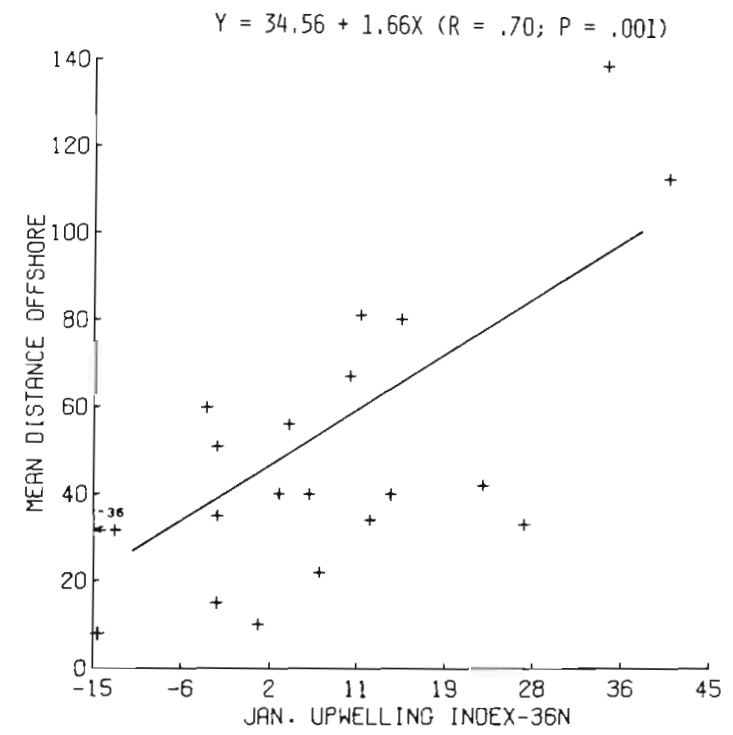

Fig. 4. Merluccius productus. Distribution of larvae offshore in January-February surveys versus January upwelling index, 1950-79 (Iinear correlation coefficient, $r=0.70 ; \mathrm{P}<$ 0.0011 these months were either spawned in January, usually the main month of spawning, or that their distribution is mostly affected by conditions in January. Survey data from these months were combined and compared to the January upwelling index in Fig. 4. The distance of larvae offshore in March is most highly correlated to Ekman transport in February.

As the upwelling season develops, larvae are found progressively farther offshore. The mean upwelling index increases from 5 in January to 73 in March; likewise the mean distance of larvae offshore increases from 37 to 84 miles (Table 3 ).

Table 3. Merluccius productus. Mean monthly distance (nautical miles) of whiting larvae offshore in the grid region compared to the mean monthly upwelling index at $36^{\circ} \mathrm{N}$ for the same years. Upwelling units are in $\mathrm{m}^{3} \mathrm{~s}^{-1} 100 \mathrm{~m}^{-1}$ of coastline

\begin{tabular}{|lccc|} 
Month & $\begin{array}{c}\text { Mean } \\
\text { upwelling } \\
\text { index }\end{array}$ & $\begin{array}{c}\text { Mean } \\
\text { distance } \\
\text { offshore }\end{array}$ & $\begin{array}{c}\text { Number } \\
\text { of } \\
\text { observations }\end{array}$ \\
\hline January & 5 & 37 & 16 \\
February & 22 & 71 & 11 \\
March & 73 & 84 & 13 \\
\hline
\end{tabular}

Paleo-oceanographic data that can be used to relate the distribution of hake larvae and offshore transport are available from records of hake scale deposition in the anoxic sediments of the Santa Barbara basin $\left(32^{\circ} 15^{\prime} \mathrm{N}, 120^{\circ} 00^{\prime} \mathrm{E}\right)$ from the study of Soutar and Isaacs (1974). The records of hake scale deposition are in 5 years increments. Hake begin to deposit scales as post-larvae of $35 \mathrm{~mm}$ (Ahlstrom and Counts, 1955); $98 \%$ of hake scales in the sediments are from 0 - and 1 aged fish. Compared to 5 year averages of January upwelling indices (available back to 1946) over the same years, there is an inverse relationship between the log-transformed variables of the abundance of hake scales in this inshore basin and offshore transport (Fig. 5; $r=0.79 ; 0.05<P<0.10$ ). These results are compatible with the hypothesis that in periods of strong January offshore transport 0 - and 1-aged hake are present in low abundance over the nearshore region.

It was possible to examine further the relationship between upwelling and the abundance of hake scales in sediments back to 1900 from historical records of sea level heights in San Francisco (USA), since sea level height is inversely related to upwelling (Smith, 1974). However, to remove a long term trend for rising sea level I have used 5 year means of the residuals (sea level anomaly) from the regression of sea level height (SL) on year (YR) to compare against hake scale deposition rates $(\mathrm{SL}=2.3 \mathrm{YR}+6898.0 ; \mathrm{r}=0.61 ; \mathrm{P}<0.01)$. Scale deposition rates in the late 19 th and early 20 th 
centuries were much higher than those observed in the past 50 years. These high rates appear to have resulted from levels of high spawning stock biomass and favorable conditions for onshore advection (Fig. $6 ; \mathrm{r}=0.55$; $\mathrm{P}<0.05$ ). A period of strong onshore advection in 1940-44 did not result in a marked increase in deposition, probably because the spawning stock biomass was low.

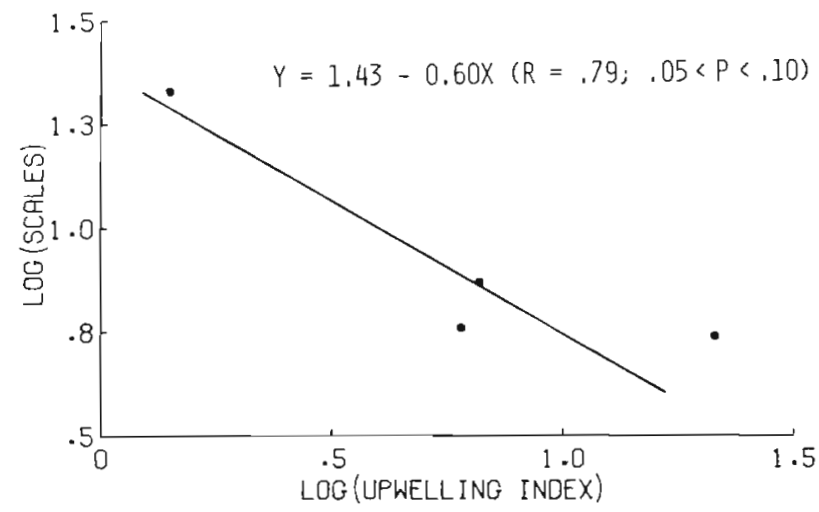

Fig. 5. Merluccius productus. Average January upwelling index over 5 year intervals versus deposition of hake scales in the Santa Batbara basin

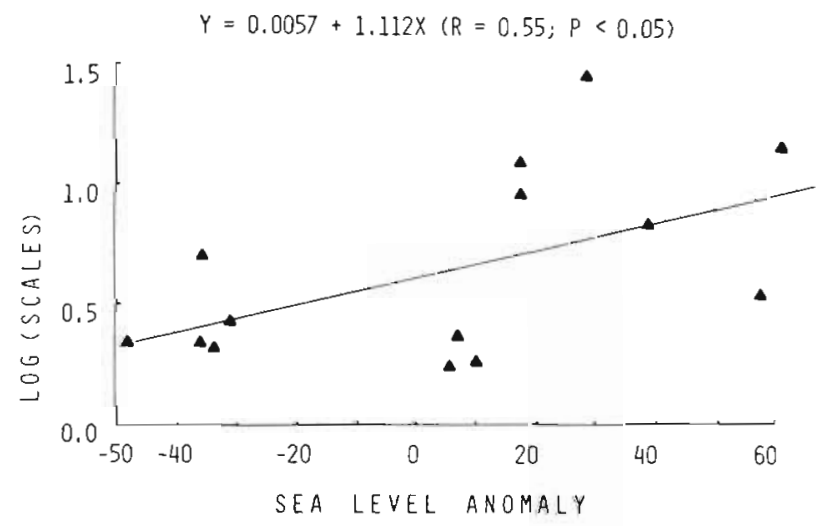

Fig. 6. Average January anomaly of sea level height in San Francisco over 5 year periods versus the deposition of hake scales in the Santa Barbara basin. Negative values indicate upwelling periods

\section{Offshore Transport and Recruitment}

Favorable environmental conditions during spawning, and especially onshore Ekman transport, are associated with the appearance of strong year classes in the Pacific hake population. From the results presented above on the distribution of larvae, Ekman transport conditions during the main months of spawning, January or February, were compared to the year class index. I assumed that a month-long 'window' of favorable transport conditions could retain eggs and larvae inshore beyond when they are vulnerable to offshore transport. Averaging of transport indices would result in lost information. For 16 years of data, a cohort's dominance of the catch composition is significantly correlated with wintertime Ekman transport in the year of spawning (Fig. 7). The 3 strongest year classes of Pacific hake in recent years: 1961, 1970 and 1973 were recruited from spawning in winters of the strongest onshore transport since 1950. A period of onshore advection of eggs and larvae is apparently contributing to the formation of strong year classes.

To examine the causative factors of this correlation, the distribution of post-larval and juvenile hake was studied to determine the fate of larvae transported beyond the continental shelf. Over 1400 midwater trawls (117 that caught 0 -aged hake) taken during 1963-75 by the California Department of Fish and Game and 666 bottom trawls taken during the summer of 1977 by the NWAFC were used to describe the distribution of juveniles.

In spring midwater trawl surveys (April to June), 0aged hake were mostly caught over the continental shelf and slope, although some hake occurred over

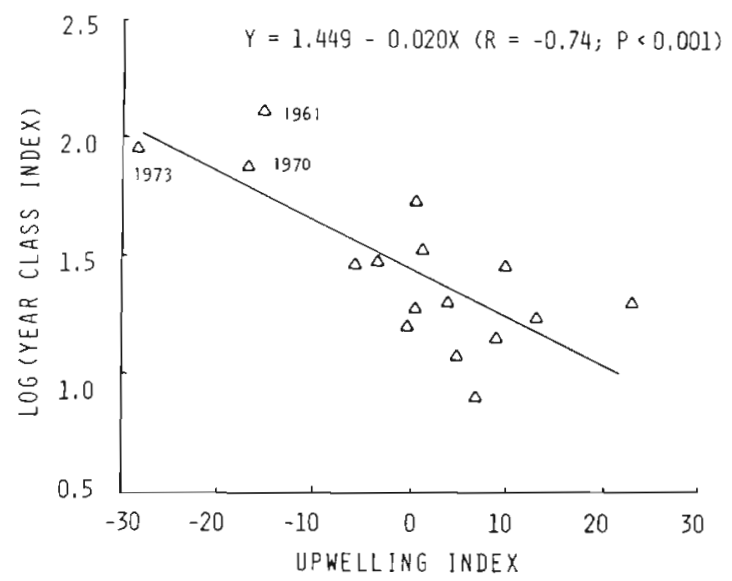

Fig. 7. Merluccius productus. Log of the year class index against the January upwelling index

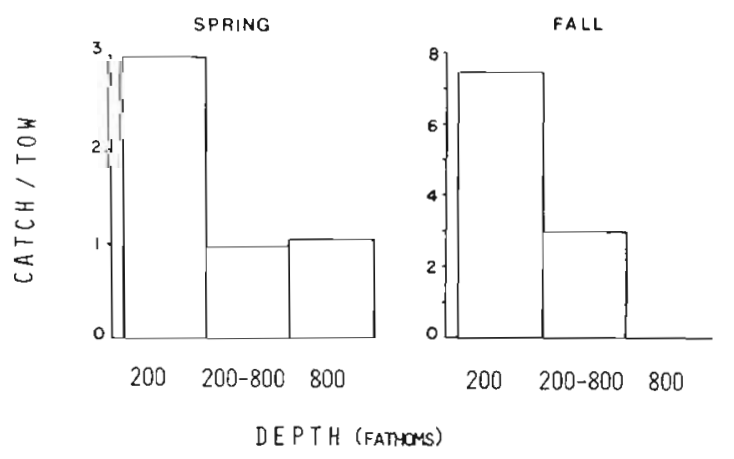

Fig. 8. Merluccius productus. Catch/tow of 0 -age hake in midwater trawls by depth zone (shelf, less than 200 fathoms; slope, 200-800 fathoms; deep water, greater than 800 fathoms) 
deep water (greater than 800 fathoms; Fig. 8). The size range of hake caught over deep water apears restricted compared to hake caught over slope and shelf depths, suggesting that the growth of hake offshore is relatively poor (Fig. 9). In autumn surveys $0-$ age hake were not found over deep water at all, but were mostly over the shelf. A similar distribution is observed in the summer bottom trawl data. Ninety-five percent of the estimated biomass of 0 -age hake is in water less than 100 fathoms deep (Table 4).

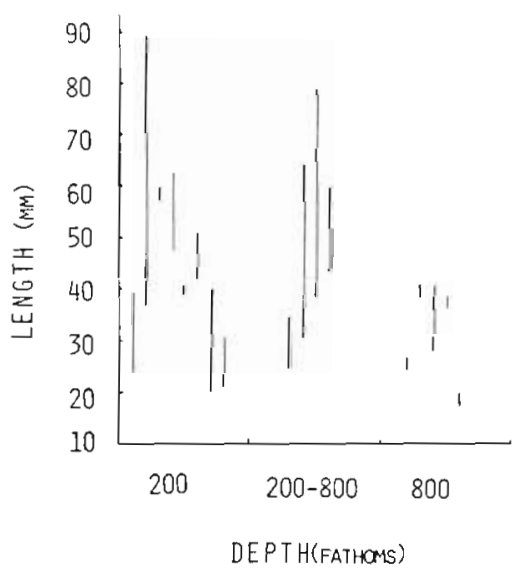

Fig. 9. Merluccius productus. Size ranges of 0-age hake caught in midwater trawls in spring crulses, by depth zone

Table 4. Merluccius productus. Percent biomass of juvenlles by depth interval and by age from the summer 1977 NWAFC bottom trawl survey

\begin{tabular}{|crrrr|}
\hline $\begin{array}{c}\text { Depth } \\
\text { (fathoms) }\end{array}$ & \multicolumn{5}{c}{ 0 } & 1 & \multicolumn{2}{c}{ Age } & \multicolumn{1}{c|}{3} \\
\hline $0-99$ & 95.4 & 35.8 & 14.6 & 20.7 \\
$100-199$ & 4.5 & 63.4 & 59.6 & 41.8 \\
$150-199$ & $\frac{0.2}{100}$ & $\frac{0.8}{100.0}$ & $\frac{25.8}{100.0}$ & $\frac{27.5}{100.0}$ \\
& 100.0 & & & \\
\hline
\end{tabular}

Table 5. Merluccius productus. Weights (dry g) and lengths (mm-SL) of aged larvae caught inshore and at one offshore station in a midwater trawl survey in June 1979

\begin{tabular}{|c|c|c|c|c|c|}
\hline \multirow[b]{2}{*}{ Age (d) } & \multicolumn{3}{|c|}{ Inshore weights } & \multicolumn{2}{|c|}{ Offshore weights } \\
\hline & Mean & Range & \# & Weight & $\#$ \\
\hline $40-42$ & .0043 & $.0030-.0060$ & 4 & .0032 & 1 \\
\hline $42-44$ & .0046 & $.0041-.0052$ & 2 & 0023 & 1 \\
\hline \multirow[t]{2}{*}{$46-48$} & .0067 & $.0042-.0129$ & 6 & .0038 & 1 \\
\hline & \multicolumn{3}{|c|}{ Inshore lenghts } & \multicolumn{2}{|c|}{ Offshore lengths } \\
\hline Age & Mean & Range & $\#$ & Length & $\#$ \\
\hline $40-42$ & 14.6 & $13.8-16.0$ & 4 & 11.1 & 1 \\
\hline $42-44$ & 16.3 & $16.0-16.7$ & 2 & 13.2 & 1 \\
\hline $46-48$ & 17.7 & $16.1-19.0$ & 6 & 15.0 & 1 \\
\hline
\end{tabular}

Data provided to me by R. Methot (Southwest Fisheries Center, La Jolla, CA, USA) also suggest that the growth of hake in the offshore region is relatively poor. Three large post-larval hake caught at one offshore station in June, 1979 were smaller in length and weight than equal-aged hake caught over the shelf (Table 5).

To examine larval survival further, an index of larval survival was formed from the number of larvae greater than $10 \mathrm{~mm}$ caught in April CalCOFI surveys, divided by the relative number of larvae spawned, calculated from January surveys as described earlier in this paper. April surveys were used in this analysis because large larvae are most abundant in this month, and next to January, April was the second most surveyed month of the CalCOFI records.

The larval survival index was compared to two environmental factors related to larval survival: (1) offshore Ekman transport, possibly causing larvae to be distributed in offshore areas of low food abundance; (2) wintertime sea surface temperature, which is related to upwelling, the latitudinal distribution of larvae, development rates, etc. Temperature was most closely correlated to the larval survival index (Fig 10; $r$ $=0.88 ; \mathrm{P}<0.011$. Ekman transport was not as closely correlated $(r=-0.58 ; \mathrm{P}<0.10)$, but excluding one year from the analysis, 1964, which was a warm year of strong offshore transport and high larval survival, a better correlation is attained $(\mathrm{r}=-0.96)$. Assuming that Ekman transport and temperature act independentiy on larval survival, they account for $92 \%$ of the variance in larval survival in a multiple regression model (Table 6).

Similarly a multiple regression model was formed to

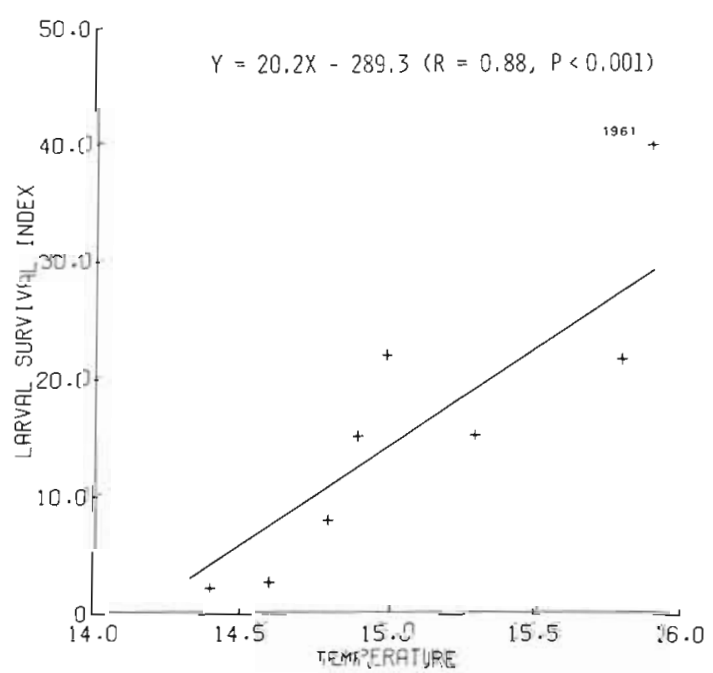

Fig. 10. Merluccius productus. Larval survival index compared to mean January to March sea surface temperature in the Los Angeles Bight. Appropriate data were available from the years $1955,1960,1961,1963,1964,1965,1966$, and 1969 
Table 6. Results of stepwise multiple linear regression model index of larval survival

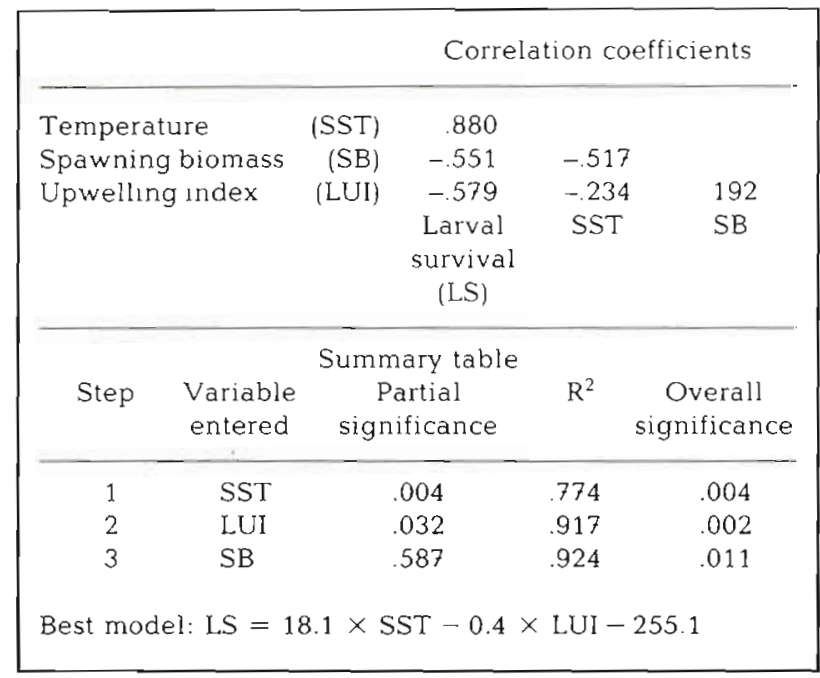

explain the variability in the index of year class strength. In the stepwise forward model the following variables were considered: (1) the relative spawning biomass (SB), estimated from the larval abundance; (2) Ekman transport ( $U$ 1); and (3) sea surface temperature (SST). As bevore, sea surface temperature and Ekman transport are themselves loosely correlated, but I considered them as factors acting independently to influence recruitment. From the results of the regression, upwelling and temperature were found to be significant variables for inclusion in the model, but spawning biomass was not. My interpretation is that within the 16 year period of observation, spawning biomass did not flucuate significantly enough to influence recruit-

Table 7 Results of stepwise multiple linear regression: Index of year class strength. $\mathrm{SB}=$ Spawning biomass; $\mathrm{T}=$ Mean January to March SST in LA Bight; LUI = Lowest of January or February upwelling indices at $36^{\circ} \mathrm{N}$; LYCI $=$ Log (year class index)

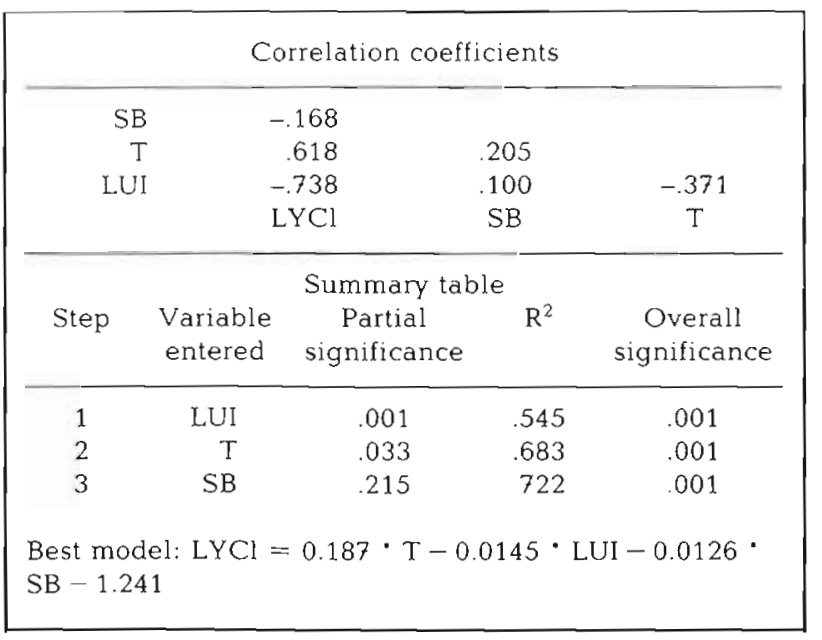

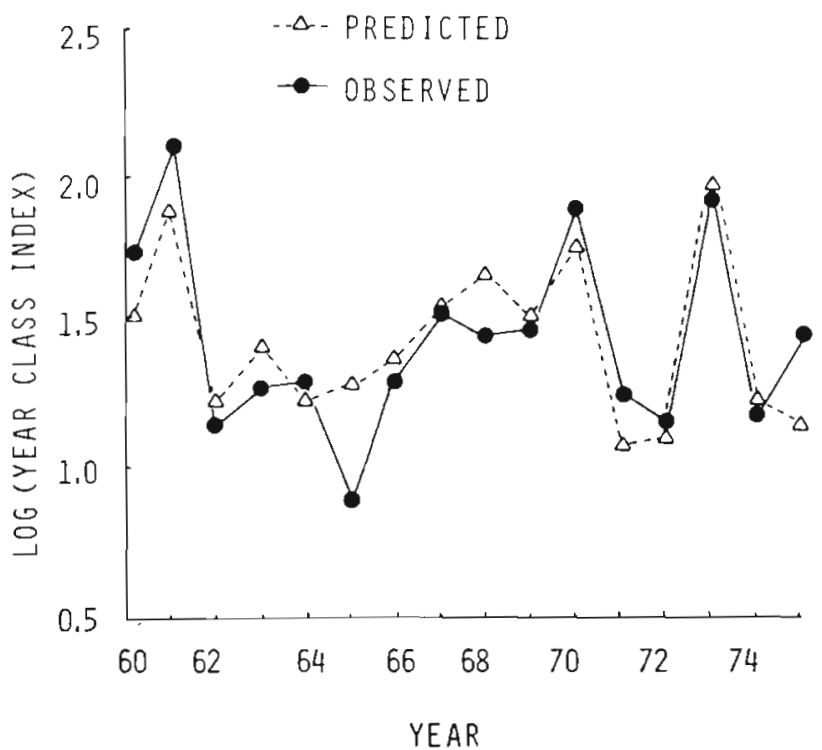

Fig. 11. Merluccius productus. Observed index of year class strength compared to predicted value from multiple regression model

ment. However, from a biological standpoint, spawning biomass should perhaps be included in the model, as it must have some effect on recruitment. The final model accounts for $72 \%$ of the variability in the index of year class strength (Table 7; Fig. 11).

\section{DISCUSSION}

The observations in this study suggest that the offshore transport of Merluccius productus eggs and larvae plays a major role in determining the success of Pacific hake recruitment. For 18 years of data the offshore distribution of hake larvae is significantly correlated to offshore Ekman transport away from the juvenile nursery. Since the juvenile nursery is inshore over the continental shelf, eggs and larvae carried offshore may have poor survival as post larvae or as juveniles. This hypothesis is supported by a significant negative correlation between a cohort's dominance of the catch composition as adults and offshore Ekman transport when spawned. The direct cause of the association between offshore transport and recruitment still needs to be critically tested; however, growth of larvae in the offshore region appears to be poor This hypothesis is supported by available data, but a welldesigned survey to study larval growth patterns is needed to further test this hypothesis. Predation on larvae by pelagic fishes in the offshore region may also be an important factor influencing survival.

Hake larvae swept seaward (sometimes up to 100 nautical miles beyond the continental shelf) may find food supplies of the right kind inadequate for success- 
ful growth. Arthur (1977), examining the feeding conditions for anchovy larvae in the Los Angeles Bight, found that copepod nauplii and microzooplankton were 4-5 times less abundant in offshore regions compared to over the shelf. This scarcity of zooplankton as food may explain why growth of hake larvae in offshore regions is poor compared to over the shelf. These larvae that are swept offshore may starve, or being in a weakened condition, may be more vulnerable to predators.

The hypothesis that offshore advection is detrimental to recruitment success is supported by other studies where correlations have been found between year class strengths of fishes with inshore nurseries and Ekman transport (Ketchen and Forrester, 1966; Nelson et al., 1977). Unlike the present study, these have not demonstrated that larvae are actually transported offshore, but have relicd on this assumption for the conclusion that it is a significant process in recruitment. Furthermore, in the California Current region, 1961, a year of strong onshore transport, resulted in strong year classes not only for hake, but also for other species with inshore nurseries, including English sole (Hayman and Tyler, 1980) and Pacific Ocean perch (Gunderson, 1977).

The positive correlation between the larval survival index and sea surface temperature also indicates that onshore transport is beneficial to larval survival, since onshore transport and sea surface temperature are correlated. However, in this study I consider the effects of offshore transport and temperature to act independently on the survival of larvae. Ocean temperatures may have a more direct effect on survival, which has not been clarified in this study. Larvae may be deeper when sea surface temperatures are warmer. This has been shown for silver hake larvae (Fahay, 1974), and may locate larvae out of the depth range of epipelagic planktivorous predators, and also place larvae below the Ekman layer. Faster development through egg and yolk sac stages is also caused by warmer temperatures, which probably decreases invertebrate predation. Finally, spawning appears to occur farther north in warm years where food supplies may be greater (see Isaacs et al., 1971) and/or predation rates are lower.

The life history of Pacific hake is well-adapted to minimize the problem of offshore larval transport. Most spawning occurs in early winter when offshore Ekman transport is at a seasonal low in the spawning region from $27-36^{\circ} \mathrm{N}$ latitude (Bakun, 1975). Further, the deep vertical distribution of eggs and larvae, which are normally found at the base of the mixed layer (Ahlstrom, 1959), protects larvae from offshore transport. Offshore transport may happen by any of several mechanisms. In upwelling conditions, when the top of the pycnocline is shallow, turbulent entrainment of eggs within the mixed layer may occur and thus they could be transported offshore at high speeds. In downwelling or weak upwelling when the mixed layer is deep, eggs and larvae would be relatively protected from short-term conditions of offshore transport. However, if surface water is moving onshore, subsurface water must be moving offshore, although probably at low speeds.

In weak upwelling conditions eggs may actually be carried inshore with subsurface water. If extreme upwelling and shoaling of the pycnocline occur, winddriven turbulence may erode the density gradient and hake eggs and larvae could rise towards the surface in response to a change in density. Support for this hypothesis comes from the observed density of eggs compared to density profiles in upwelling and downwelling years. The average density of hake eggs at neutral buoyancy is $1.0253 \mathrm{~g} \mathrm{~cm}^{-3}$ (range = 1.0247-1.0263) as calculated from Ahlstrom's (1959) data on the depth distribution of hake eggs and the density of water at the depth of capture. Compared to density profiles in 1951, a year of upwelling, and in 1961, a year of downwelling, eggs in theory would be at the surface in 1951 and relatively deep in 1961 (Fig. 12). Larvae were located far offshore in 1951. One might expect that if the eggs were close to the surface, they would have been highly vulnerable to winddriven transport offshore. Ahlstrom's data showing the vertical distribution of eggs and larvae also supports this hypothesis. Larvae tended to be distributed closer to the surface, and sometimes at the surface, when the water column was less stratified.

An alternate mechanism which may cause larvae to

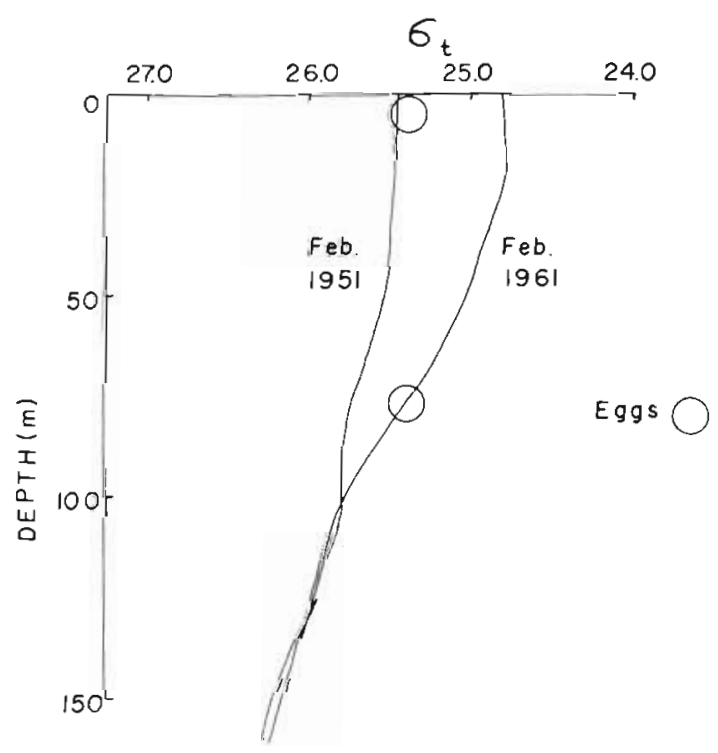

Fig. 12. Merluccius productus. February density protiles in 1951 and 1961 at Station 80.60 shown with theoretical depth of eggs based on an average egg density of $1.0253 \mathrm{~g} \mathrm{~cm}^{-3}$ 
be distributed far seaward of the continental slope is offshore spawning. Although spawning schools are sometimes located offshore (Bailey 1981), the major location of spawning within the grid region of this study appears to be over the continental slope, as determined from the distribution of eggs and small larvae. If the correlation between the offshore distribution of larvae and Ekman transport is due to an indirect mechanism like the location of spawning, then the offshore distribution of larvae should be related to a factor like temperature or fronts, which does not appear to be the case.

Acknowledgements. Discussion with Drs. R. Parrish, P. Smith and $W . S$. Wooster contributed to the ideas in this study. Appreciation is extended to Drs. W. S. Wooster, G. Stauffer, D. Gunderson, M. Tillman, R. Francis and D. H. Cushing for editing the manuscript and making suggestions; to $T$ Dark and G. Moser for supplying some data. This project was funded by the Northwest and Alaska Fisheries Center

\section{LITERATURE CITED}

Ahlstrom, E. H. (1959). The vertical distribution of fish eggs and larvae off California and Baja California. Fish. Bull. U. S. $60: 107-146$

Ahlstorm, E. H., Counts, R. C. (1955). Eggs and larvae of the Pacific hake, Merluccius productus. Fish. Bull. U. S. 56: 295-329

Arthur, D. K. (1977). Distribution, size and abundance of microcopepods in the California Current system and their possible influence on survival of marine teleost larvae Fish. Bull U. S. 75: 601-612

Bailey, K. M. (1980). Recent changes in the distribution of hake larvae: causes and consequences. CalCOFI Rept. 21 : $167-171$

Bailey, K. M. (1981). An analysis of the spawning, early lite history and recruitment of the Pacific hake, Merluccius productus. Ph. D. dissertation, University of Washington, Seattle

Bakun, A. (1973). Coastal upwelling indices, west coast of North America, 1946-71. NOAA Techn. Rept. NMFS, SSRF-671
Bakun, A. (1975). Daily and weekly upwelling indices, west coast of North America, 1967-73. NOAA Tech. NMFS, SSRF-693

Elliott, J. M. (1977). Some methods for the statistical analysis of samples of benthic invertebrates. Freshw. Biol. Ass Spec. Pub]. No. 25

Fahay, M. P. (1974). Occurrence of silver hake, Merluccius bilinearis, eggs and larvae along the middle Atlantic continental shelf during 1966. Fish. Bull. U. S. 72: 813-834

Gunderson, D. R. (1977). Population biology of Pacific Ocean perch, Sebastes alutus, stocks in the Washington-Queen Charolotte Sound region, and their response to fishing. Fish. Bull. U. S. 75: 369-403

Hayman, R. A., Tyler, A. V (1980). Environment and cohort strength of Dover sole and English sole. Trans. Am. Fish. Soc. 109: 54-70

Isaacs, J. D., Fleminger, A., Miller, J. K. (1971), Distribution atlas of zooplankton biomass in the California Current region, winter, 1955-59. CalCOFI Atlas No. 14

Johnson, J. H., McLain, P. R., Nelson, C. S. (1978). Climatic changes in the Pacific Ocean-an update through 1975. NOAA Tech. Rept. Circ. 416: 103-125

Ketchen, K. S. (1956). Factors influencing the survival of lemon sole (Parophrys vetulus) in Hecate Strait, British, Columbia. J. Fish. Res. Bd Can. 13: 647-694

Ketchen, K. S., Forrester, C. R. (1966). Population dynamics of the petrale sole, Eopsetta jordani, in waters off western Canada. Fish. Res. Bd Can. Bull. 153

MacGregor, J. S. (1966). Fecundity in the Pacific hake, MerIuccius productus. Calif. Fish Game 52: 111-116

Nelson, W R., Ingham, M. C., Schaaf, W E. (1977). Larval transport and year class strength of Atlantic menhaden, Brevoortia tyrannus. Fish. Bull. U. S. 75: 23-42

Riley, J. D., Symonds, D. J., Woolner, L. (1979). On the factors influencing the distribution of 0 -group demersal fish in coastal waters. ICES/ELH Symposium/DA: 1

Smith, P. E., Richardson, S. L. (1978). Standard techniques for pelagic fish egg and larva surveys. FAO Fish. Tech. Paper No. 175

Smith, R. L. (1974). A description of current, wind and sea level variations during coastal upwelling off the Oregon coast, July-August 1972. J. Geophys. Res. 3: 435-443

Soutar, A., Isaacs, J. D. (1974). Abundance of pelagic fish during the 19th and 20th centuries as recorded in anaerobic sediments off California. Fish. Bull. U. S. 72 : 237-274 